\title{
Abused Refugee Women: Trauma and Testimony
}

\author{
Inger Agger
}

This paper discusses a number of issues generated by my experience as a therapist and a researcher in the area of human rights violations against women. I am especially concerned with issues of ritual space, gender, testimony, and victimization. As coordinator of psychosocial projects for war-traumatized women and children in the former Yugoslavia, I have witnessed the extensive use of sexuality as a repressive tool against women, namely the very high incidence of rape that is used as a weapon of war directed at both the women themselves and at their families and their people.

With respect to the issue of ritual space, I will discuss how I attempted to create such a space during interviews with 40 traumatized refugee women and in my own subsequent writing. Next, I will consider the gender-specific abuse of women, which falls within the realm of human rights violations of women. I will also outline some of the ways I have used testimony therapeutically within a ritual space. Lastly, I will look at some issues connected with sexual victimizationfocusing in particular on the problem of complicity and the power of shame.

I use the concept of human rights based upon the United Nations Universal Declaration of Human Rights as my point of departure. This perspective focuses on universal cross-cultural rights and, in the case of refugee women, it directs attention towards universal similarities instead of cultural differences. Moreover, the ethical dimension of universal human rights has implications in my therapy practice: it places the blame outside of the victim, and also forces the therapist to take a moral stand. I find that the

Inger Agger was formerly a member of the European Task Force in Zagreb, Croatia, and currently works at the Centre for Psychosocial and Traumatic Stress, Aalborg Psychiatric Hospital, Denmark. concept of human rights can serve as a sort of epiphany for both patient and therapist. For many refugees, it comes as a surprise that they have any rights at all. They are surprised to discover that the international community has accepted their right to a dignified life. Such revelations may be the first step in a consciousness-raising process, or a process of post-traumatic therapy. Growing awareness of the ethical dimensions of the human rights concept may also be the beginning of a consciousness-raising process for the therapist. There is increasing discussion in the field of post-traumatic therapy of how we, as therapists and researchers, react to horrifying and traumatic stories about deliberate hu-

low the victim to become a survivor, and the therapist or researcher to convert his or her own pain into a struggle for human rights.

I had worked for five years as a therapist for torture victims when I decided that I needed to translate some of my experiences into theory and additional research. The research project I planned was governed by an attempt to understand some of the strange and terrifying experiences which my female patients had told me about, in particular, the use of sexuality as a means of torture in the political prisons. But it was also governed by an attempt to rid myself of some of the evil I, as a therapist, had to confront in the women's stories. It was an attempt

\section{For many refugees, it comes as a surprise that they have any rights at all. They are surprised to discover that the international community has accepted their right to a dignified life. Such revelations may be the first step in a consciousness-raising process, or a process of post-traumatic therapy.}

man rights violations. How do wewho are supposed to be the victims' helpers and counsellors-manage our own pain?

Human rights violations are a worldwide problem. Violations of women's rights are widespread and growing in the industrialized societies of the West, in the developing countries and, of course, in the former $\mathrm{Yu}$ goslavia where I worked. Therapists working with victims of trauma encounter women and girls who have experienced gender-specific human rights violations-be it refugee women who have been sexually abused in camps, in their homes or during flight, or Western victims of rape, wife-battering, incest, or prostitution. Therapists and researchers are, therefore, confronted with the problem of how to create a space which becomes healing for both the victims and the therapist, a space that will al- both to purify myself by giving meaning to the unbelievable stories I had heard as well as to offer my own testimony of what it feels like to meet deliberate human evil. The research project involved interviews with 40 refugee women ( 20 from the Middle East and 20 from Latin America) and, inevitably, I was again experiencing the therapist's problem of containing the trauma story as all the women told me their life-stories. Although I was now acting as a researcher, it did not make much difference. For one thing, I could not just forget my clinical background. Secondly, my clinical background was very valuable for the interview process, because it gave me the courage to explore parts of the trauma story that were important to document from a theoretical and human rights point of view.

So I tried to create a ritual space, which I called "the blue room." In fact, 
the walls of the room in which I carried out the interviews were painted blue. But I also use "the blue room" as a metaphor for the space in which the interviews took place. In this room the woman and I together created a space which I, inspired by the anthropologist Kirsten Hastrup (1987), have called "the third culture." While we might come from different cultures, in the blue room we created something new and different-a third culture-to which we both contributed. It was in this context that the story was told by her and heard by me.

At the beginning of each meeting in the blue room I would explain the purpose of my research project, namely to learn more about the special conditions of refugee women and to publish this information, so that people in asylum countries might know more about the human rights violations perpetrated against women. I would also disclose information about my own background: that I had worked for several years as a therapist for torture victims, and that I was not "neutral" as a researcher. I expressed my opinion that it was important that the world know what happens to women. In this way I tried to establish an atmosphere of compassion and solidarity.

An important component of the ritual space of the blue room was the tape recorder. I began each interview by testing the tape recorder. For this test, I had the woman say her name, age, and nationality. I would then play the tape back. Together we listened and confirmed that the woman's voice was recorded, and that it could be heard in the blue room. Then we started recording the interview. The woman being interviewed then knew that her voice and her name could be heard. We were ready to start her testimony.

In the meetings with the refugee women in the blue room, I used testimony as a research method. Thus I attempted to unite the use of testimony in the consciousness-raising groups of the women's movement with experiences from my therapeutic training and my work with testimony as a transcultural therapeutic method. The use of this method implies that research and therapeutic processes can overlap. For victims of human rights violations, testimony has a special significance because it serves as a documented accusation and a piece of evidence against the repressive system. "Testimony" as a concept has a special, double connotation: it contains objective, judicial, public, and political elements, as well as subjective, spiritual, cathartic, and private ones. Testimony thus has the capacity to unite the private and the public spheres (Agger and Jensen 1990).

In Chile during the dictatorship, testimonies were used for registering and denouncing extreme examples of torture. The victims' stories were taped, transcribed, and sent to international organizations as evidence against the dictatorship. Gradually, the therapeu- or her pain. But now it is an act which is inscribed in the original existential project. The information will not be used against the comrades, but, rather, against the torturers" $(1987,67)$. During the interview process, I did not meet any women who refused to give testimony. On the contrary, they seemed to find it important to provide this "confession" against their oppressors.

All the women had suffered human rights violations. Some had been in prison and had been tortured, others had close relatives who had been tortured or murdered, still others had been forced to leave small children with relatives in their homelands in order to leave quickly and save their own lives. Some had lived clandestinely for long periods in their own countries before they could get out. After arriving in Denmark, many had

\section{I would also disclose information about my own background: that I had worked for several years as a therapist for torture victims, and that I was not "neutral" as a researcher. I expressed my opinion that it was important that the world know what hap- pens to women. In this way I tried to establish an atmosphere of compassion and solidarity.}

tic value of the method also became evident and a series of reflections started on the possibilities and limitations of such a method for the healing of emotional wounds resulting from torture. Psychologists Eugenia Weinstein and Elizabeth Lira (Weinstein, Lira, Rojas et al. 1987) observed that giving testimony alleviated symptoms and transformed a painful experience into a document that could be useful to other people. It was not only cathartic, but also acted as a political and legal weapon against the aggressors. In this way, some of the aggression that the abuse had created in the victim could be redirected in a socially constructive manner, thereby breaking a self-destructive spiral. "It is a paradox," Weinstein and Lira noted, "that the testimony in some ways is a complete confession-that which they tried to extract by means of torture and which the subject protected at the cost of his lived for months in refugee camps anxiously waiting for asylum to be granted.

Nearly all the refugee women in my research project had made themselves "visible" through their political activity. They were well-educated and anxious to talk about the conditions in their homelands. In this way, they could describe in vivid detail the circumstances of their own lives and of those of their silent sisters in poorer conditions.

Through their testimonies, I tried to understand how sexual abuse of women who belong to a certain "dangerous" group is connected with the surrounding sexual and political power structure and with the historically transmitted definitions of "the shameful" and "the unclean." This could, I thought, add to the understanding of the paradoxical feeling of complicity that can arise in a person 
who is subjected to sexual as well as other forms of abuse.

It was my hypothesis that an understanding of the social and psychological dynamics of this problem of complicity would provide greater insight into one's own counselling practices with women who have suffered human rights violations. It would also allow for a better understanding of the dynamics of other forms of sexual trauma, e.g. rape, incest, and women battering.

Once the interviewing process was completed, I transcribed those parts of the women's testimonies which I found relevant to the questions I had proposed in my research project. This left me with pages of testimonies and I was alone in the blue room with my collection of trauma stories. It was now up to me to write my testimony of what I had seen, heard, thought, and felt.

I chose then to expand the ritual space of the blue room into the written text by using two key metaphors: rooms in a house, and boundaries between spaces. The blue room was the space in which the interviews took place. There is also the "mother's room," the "father's room," the "cell," the "children's room," the "living room," and the "veranda." Each room represents a different kind of experience and relationship in the women's lives. The metaphor of boundaries, especially crossing boundaries, symbolizes the problematic danger in the lives of the interviewed women.

I wrote my narrative in a certain style in which I used metaphorical language as a way of expressing my own counter-transference reactions. I thus attempted to heal the trauma in the ritual spaces of each room. In the last chapter, "The Veranda," I created a metaphorical healing circle in which I let the voices of the women speak to each other-in this way suggesting that one important tool for healing is for the victims to get together in such ritual spaces as a way of giving testimony in an atmosphere of compassion and understanding.

The testimony of the refugee women expressed a virtually univer- sal pattern of female oppression. This universal pattern expresses itself in a whole range of human rights violations against women, such as rape, wife battering, incest, and prostitution. The common characteristic of all these forms of gender-specific abuse is the violation of the woman's right to her own body - to her physical and psychological integrity-and ultimately to a life of dignity. The gender-specific issues in all these examples of human rights violations of women revolve around sexuality and the way in which it is used as a means to control, exploit, and punish women.

In women's lives, in most parts of the world, the significant definitional spaces are those which are connected with sexuality and reproduction. It is, therefore, also within those definitional spaces that the social and political control of women is exercised. I see these mechanisms of social con-
Danger (1966), by the British anthropologist Mary Douglas.

I have taken as my point of departure the almost universal ambivalence towards women's blood, be it menstrual blood or the blood from the first intercourse. This blood is an exterior sign of the movement from one social condition to another. The first menstruation marks the transformation from girl to virgin, while the blood after the first intercourse marks the shift from virgin to woman. Both are symbols of status, of social boundaries that are crossed, and also of social boundaries that have been violated. Through the societal attitude to her blood, the girl learns about the shameful dangers that people find threatening.

One of the most serious dangers that threaten people is that of contamination or impurity. If, for example, there is no blood on the wedding night, this could be a sign that the girl has been

\section{The common characteristic of all these forms of gender-specific abuse is the violation of the woman's right to her own body-to her physical and psychological integrity - and ultimately to a life of dignity.}

trol of dangerous, i.e. vocal, women as clear-cut examples of the social control that also governs the lives of their more silent and invisible sisters.

If women leave the private sphere to enter the public one, speak up and become visible in, for example, sexual or political revolts, this can create a crisis in the system. It can cause disorder and contamination, and it represents a special threat if the system is already in a state of crisis (Goddard 1987). Thus visible women become dangerous women.

Yet, when both the silent and the dangerous women are hit in their souls by the sexual control mechanisms of society, they very often blame themselves. Why does the victim blame herself? This problem of complicity must involve deep-seated feelings and values that are part of the unconscious of both the individual and the societal structure. I have analyzed the question from an anthropological perspective inspired by a book entitled Purity and involved in forbidden sexual acts. If there is no menstrual blood, the implication could be the same. Regardless of how the forbidden has happened, or whether it happened with or without her consent, she is nevertheless an accomplice. She could have been more careful. She learns that it is her responsibility, that she has to be careful that she does not bring shame on herself or on her family.

Although it was never her intention to understand trauma or work in the field of therapy, I think Douglas provides some insight into the problem of complicity that is also relevant for other trauma victims, who have been involved in acts which the official ideology of society does not condone: "The ideal order of society is guarded by the dangers which threaten transgressors," writes Douglas. One of the most serious dangers threatening those who are not careful is pollution or contamination. Dirt is defined by Douglas as something which is in the 
wrongplace. The unclean and the dirty must not be present if a societal model is to be maintained. If you disturb the order of things, you expose yourself to dangerous pollution. But you do not only pollute yourself. You are also dangerous to others. One's intentions are irrelevant. The danger of pollution is a power that threatens careless human beings. As Douglas says:

A polluting person is always in the wrong. He or she has developed some wrong condition or simply crossed some line which should not have been crossed and this displacement unleashed danger for someone else." (113)

I think Douglas expresses a fundamental aspect of victimization. The victim has been involved in something which is not regarded as nice or good, neither by herself or himself, nor by society. The feeling of being wrong or dirty, then, does not have anything to do with responsibility.

We could also analyze these dynamics from the perspective of shame. Douglas' focus is on societal mechanisms of control. But if we look at the Hungarian philosopher Agnes Heller's concept of "the power of shame" (1985), we see the same mechanisms from an individual viewpoint. According to Heller, shame is the very feeling that makes us adjust to our cultural environment. Shame is universally the first and most basic moral feeling, and it is internalized by the child at a very early age. When the child learns what he or she should be ashamed of, the child simultaneously learns of the legitimization of a system of domination. The external power is internalized in the feeling of shame. This is society's silent voice, or "the eyes of the others" that we hear and sense inside of us. And the prostitute, Heller says, is the symbol of shame. She is the embodiment of lost honour.

The problem of complicity and the feelings of shame are prominent features of the trauma of torture victims, especially if they have been sexually abused. But these features are also found in the trauma of other victims. As noted by Judith Herman in her re- cent book, Trauma and Recovery (1992), the psychological impact of victimization may have many common features, whether victimization occurs within the public sphere of politics or within the supposedly private-but equally political-sphere of sexual and domestic relations.

My own research process through the woman's house of exile has not ended yet. Upon the publication of my book, The Blue Room (1994), a heated discussion ensued that involved some very personal attacks against me. One sarcastic reviewer did not trust the testimonies. Another reviewer was extremely angry and wrote that the choice of such a "perverse" topic reflected the author's own personal problems. Apparently, some readers have directed their mistrust or anger at the messenger. When we work in the field of trauma and see the effects of extreme human evil, therapists and researchers experience some of the same feelings that our clients or research-objects experience. This I see as an invaluable tool for a deeper understanding of the psychological mechanisms of trauma.-

\section{References}

Agger, I. 1994. The Blue Room: Trauma and Testimony Among Refugee Women - A Psycho-Social Exploration. London: Zed Books.

Agger, I. and S.B. Jensen. 1990. “Testimony as ritual and evidence in psychotherapy for political prisoners." Journal of Traumatic Stress, 3, 115-130.

Douglas, M. 1966. Purity and Danger. London: Routledge \& Kegan Paul.

Goddard, V. 1987. "Honour and shame: the control of women's sexuality and group identity in Naples." In P. Caplan ed., The Cultural Construction of Sexuality (166-92). London: Tavistock.

Hastrup, K. 1987. "Veracity and visibility: The problem of authenticity in anthropology." Folk, 28.

Heller, A. 1985. The Power of Shame. London: Routledge \& Kegan Paul.

Herman, J. 1992. Trauma and Recovery. New York: Basic Books.

Weinstein E., E. Lira, E. Rojas, et al. 1987. Trauma, Duelo y Reparacio'n (Trauma, mourning and reparation). Santiago de Chile: FASIC/Interamericana. $\square$

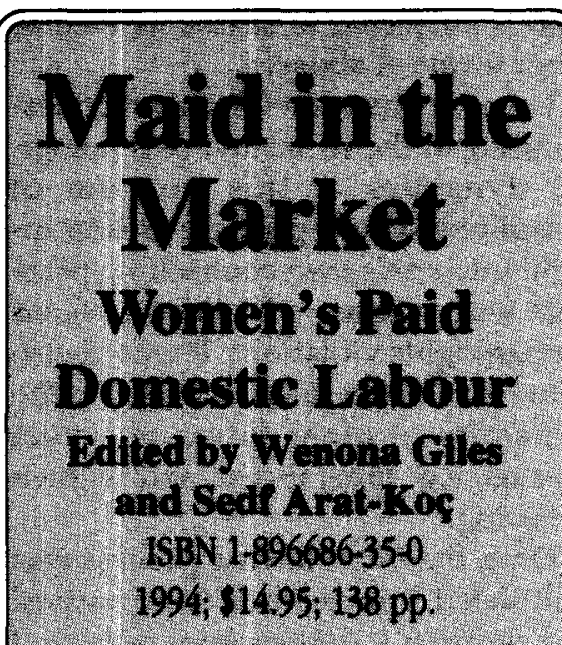

This book denonstrates that even when donein" public" and forpay, the vork of housekceping and caregiving in industral society is problematic. By focusing on three different kinds of pald "domestic work": commodified housework, service work performed in commercial settings and service work that is marketed and sold in familistic terms, the book explores how the work of reproduction is subordinated and devalued in the market place when it is done for 2 wage.

Inadditionto heissues of classand the labour process, the book also focuses on the genderand racial/ethnic dimensions of the industral solution to the reprodiction of labour porrer. Paid housenork is usually performed bywomen, especially immigrant, refugec, and working class women. The book argues for a new feminist debate on domestic work that willadress the relationship between gender, class and race/ethnic relations to arrive at an evaluation of allemaives for priva. tized housework.

Publshed by:

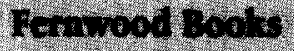

P. 0. Box 9409, Station A

Halifax Ns B3K 583

Tel. (902) $422-3302$

Fax: $(902) 422-3179$ 